\title{
BODIPY Appended Crown Ethers: Selective Fluorescence Changes for $\mathrm{Hg}^{2+}$ Binding
}

\author{
Hyun Jung Kim, Sang Hoon Kim, Ja Hyung Kim, Eil-Hee Lee, Kwang-Wook Kim, and Jong Seung Kim \\ Department of Chemistru, Korea Cniversitw, Seoul 136-701. Korea. "E-mail: jongshimiäkorea achr \\ ${ }^{\dagger}$ Korea Atomic Energv Research Institute. Daejeon 305-600, Korea \\ ReceivedJulv 1. 2008
}

Key Words : BODIPY. Crown ether, Mercury ion, PET. Fluorescence

Recently. the development of fluorescent chemosensors capable of selective recognition and sensing of metal ions is one of the most challenging fields from the vantage of organic and supramolecular chemistry. fluorescence chemosensor must convert the event of metal ion recognition by the ionophore into light signals of the fluorophore with high sensitivity and ease of monitoring. ${ }^{3.4}$ In designing sensors the ionophore linked to the fluorophore should be preliminarily considered because they are responsible for the selectivity and binding efficiency of the whole chemosensors.

There is a growing interest in synthesizing macromolecule appended fluorescence materials showing marked changes upon cation, anion, and neutral molecule complexation. aiming to develop ion-selective and sensitive material. The "hard" ether-oxygen containing macrocycles show a binding preference toward "hard" alkali and alkaline earth metal cation. but the incorporation of "soft" sulfide or amine linkages shifts its preference toward "soft" heavy metal cations." In addition. it has been demonstrated that macrocyclic ligands containing nitrogen-sulfur donor atoms can behave as highly selective complexing agents for transition metal cations. $^{67}$ In this regards. sulfur containing macrocycles such as thiacrown ethers have been prepared and their complexation properties have been investigated with various metal cations. ${ }^{\text {s-10 }}$

BODIPY (boradiazaindacenes) is well known fluorescent dye in that it gives high quantum yields. large extinction coefficients and narrow emission bands. These properties facilitated their application in many fields. such as fluorescent labeling of biomolecules. ion sensing and signaling. energy transfer cassettes. light harvesting sy stems and fluorescent stains."

Currently considerable attention has been focused on fluorescent chemosensors for the selective and rapid determination of the toxic heavy metal ions. such as the $\mathrm{Pb}^{2+}$. $\mathrm{Cd}^{2+}$, and $\mathrm{Hg}^{2+}$ ions. ${ }^{2}$ Especially. in this regard. the $\mathrm{Hg}^{2+}$ ion is considered highly dangerous because both elemental and ionic mercury can be converted into methyl mercury by bacteria in the environment, which subsequently bioaccumulates through the food chain. ${ }^{13}$ Therefore, there is a high demand for the detection of the $\mathrm{Hg}^{2+}$ ion both in environmental analysis and in industrial waste treatment.

In this paper. we report the synthesis and the fluorometric properties of BODIPY appended thiacrown 1 and crown ethers 2 and 3 . Compound 1 displayed a highly selective chelation enhanced fluorescence (CHEF) effect only with $\mathrm{Hg}^{2+}$. Similar CHEF effect was observed upon the addition of $\mathrm{Ag}^{-}$to 1 . suggesting that silver ions also bind to the thiacrown, but less strongly than does $\mathrm{Hg}^{2+}$.

Synthesis of 1-3 was achieved by adaptation of procedures reported earlier. ${ }^{14}$ 4-6 were treated with 2.4-dimethylpyrole in the presence of TFA. which were subsequently oxidized (p-chloranil). neutralized $\left(\mathrm{Et}_{3} \mathrm{~N}\right)$, and treated with $\mathrm{BF}_{3} \cdot \mathrm{Et}_{2} \mathrm{O}$

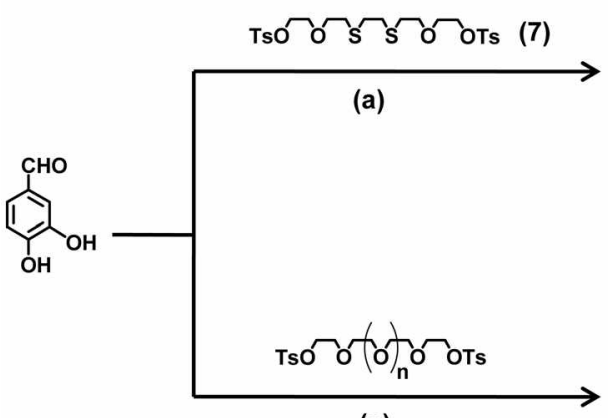

(a)

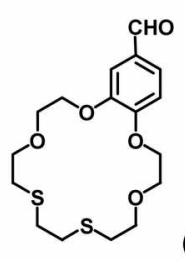

(4)

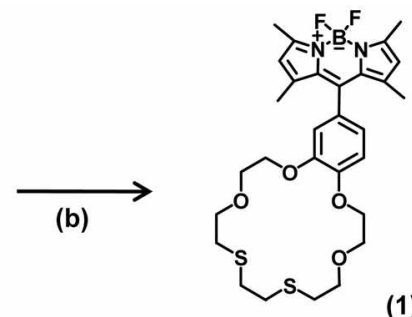

(1)

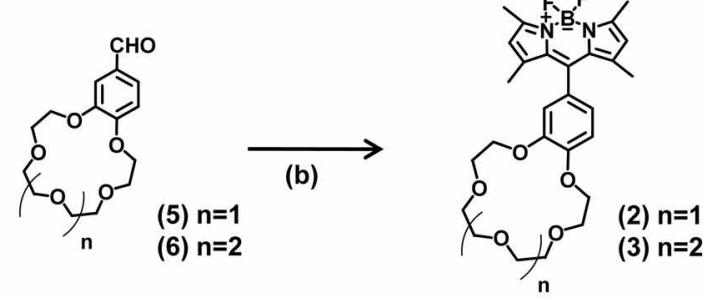

Scheme 1. Synthetic route to fluorogenic ligands 1-3. Reagents: (a) $\mathrm{K}_{2} \mathrm{CO}_{3} / \mathrm{CH}_{3} \mathrm{CN}$; (b) 2,4 -dimethylpyrrole/TFA/p-chloranili/Et ${ }_{3} \mathrm{~N} /$ $\mathrm{BF}_{3} \cdot \mathrm{Et}_{2} \mathrm{O} / \mathrm{CH}_{2} \mathrm{Cl}_{2}$ 


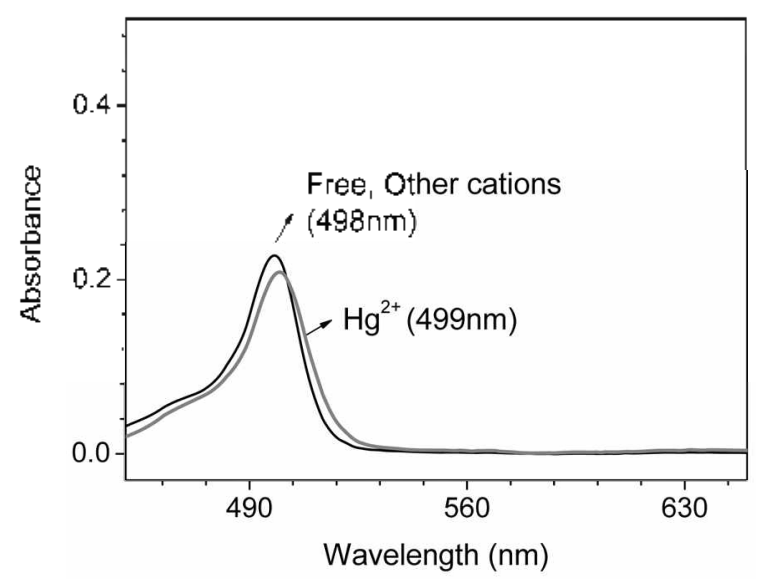

Figure 1. Absorption spectra of $1(15.0 \mu \mathrm{M})$ with addition of $\mathrm{ClO}_{4}$ salts of $\mathrm{Li}^{-}, \mathrm{Na}^{+}, \mathrm{K}^{+}, \mathrm{Rb}^{+}, \mathrm{Cs}^{+}, \mathrm{Ag}^{-}, \mathrm{Cd}^{2-}, \mathrm{Mg}^{2-}, \mathrm{Ca}^{2+}, \mathrm{Sr}^{2+}, \mathrm{Ba}^{2-}$, $\mathrm{Zn}^{2+}, \mathrm{Hg}^{2-}, \mathrm{Pb}^{2-}, \mathrm{Co}^{2-}, \mathrm{Cu}^{2+}$, and $\mathrm{Al}^{3-}$ (50) equiv, respectively) in $\mathrm{H}_{2} \mathrm{O} / \mathrm{CH}_{3} \mathrm{CN}(6: 4, v / v)$.

to produce the desired BODIPY derivatives $1-3$, respectively.

Metal ion binding properties of 1 were investigated by monitoring fluorescence and UV/vis changes upon the addition of $\mathrm{Li}^{-}, \mathrm{Na}^{+} \cdot \mathrm{K}^{-}, \mathrm{Rb}^{+} \cdot \mathrm{Cs}^{-}, \mathrm{Ag}^{+} \cdot \mathrm{Cd}^{--}, \mathrm{Mg}^{2-} \cdot \mathrm{Ca}^{2+}$. $\mathrm{Sr}^{\hat{+}} \cdot \mathrm{Ba}^{\hat{2}^{-}}, \mathrm{Zn}^{\hat{2+}} \cdot \mathrm{Hg}^{\hat{2}} \cdot \mathrm{Pb}^{3+} \cdot \mathrm{Co}^{\hat{2+}} \cdot \mathrm{Cu}^{\hat{2}^{-}}$, and $\mathrm{Al}^{3-}$ ions in $\mathrm{H}_{2} \mathrm{O} / \mathrm{CH}_{3} \mathrm{CN}(6: 4, v / v)$. The aqueous media $\left(\mathrm{H}_{2} \mathrm{O} / \mathrm{CH}_{3} \mathrm{CN}\right.$ $(6: 4=\mathrm{v} / \mathrm{v}))$ we have used in this experiment reasoned that water media are all required when fluorescence molecules can be utilized in a biological system as a fluorescent chemosensor. Free 1 showed a sharp and strong absorption band at $498.0 \mathrm{~nm}$ (Figure 1). When $\mathrm{Hg}^{2+}$ is bound to 1 . the absorption band of 1 at $498 \mathrm{~lm}$ was slightly red-shifted to $499.5 \mathrm{lun}(\Delta \lambda=1.5 \mathrm{~nm})$. However, other ions did not cause any detectable changes with 1 . To get insight into the binding mode of 1 especially two sulfur atoms for the $\mathrm{Hg}^{2+}$ binding. corresponding crowns 2 and 3 have been prepared. too. Although the crown-5 (2) and crown-6 (3) loops are well known to adopt $\mathrm{Na}^{+}$and $\mathrm{K}^{+}$ion, respectively, the UV/ Vis band shift could not be observed in this experiment. This is because the BODIPY is positioned in perpendicular to benzocrown unit. resulting in that the ICT change is no longer influenced upon metal ion binding.

The fluorescence change results are represented in Figure 2. 1 shows a pronounced selectivity and sensitivity for $\mathrm{Hg}^{3+}$ when it is irradiated at $\mathbf{4 9 9} \mathrm{nm}$. whereas $\mathbf{2}$ and $\mathbf{3}$ does less selective towards most metal cations. Similar fluorescence change was observed upon the addition of $\mathrm{Ag}^{-}$to 1 . suggesting that the silver ions also bind to the sulfur atoms, but less strongly than does $\mathrm{Hg}^{2-}$ ion. The fluorescence enlancement phenomena of 1 upon $\mathrm{Hg}^{\hat{2}-}$ binding are ascribable to the CHEF (chelation-induced enhanced fluorescence) mechanism. ${ }^{15}$ When the $\mathrm{Hg}^{3+}$ ion interacts with sulfur atoms of the thiacrown part, the PET (photo-induced electron transfer) from sulfur atoms to fluorescence BODIPY group is inhibited. With $\mathrm{Cu}^{2+}$ jons. however. a marked quenching effect was observed. Coordination of 1 to $\mathrm{Cu}$ (II) having $\mathrm{d}^{\mathrm{i}}$-electronic configuration is likely to induce the photo-induced electron transfer to give a considerable fluorescence quenching.

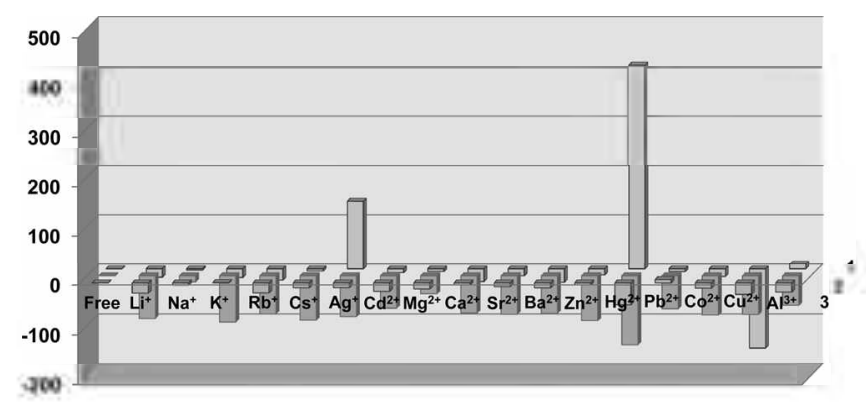

Figure 2. CHEF: tluorescence emission changes $\left(I-I_{0}\right)$ of $0.50 \mathrm{fM}$ solutions of 1-3 in $\mathrm{H}_{2} \mathrm{O} / \mathrm{CH}_{3} \mathrm{CN}(6: 4$, v/v) upon addition of 50 equiv of various metal ions. Excitation at $498 \mathrm{~mm} ; I_{\mathrm{j}}$ : fluorescence emission intensity of free 1-3. $I$ : fluorescence emission intensity of metal complexes of 1-3. (+) and (-) denote fluorescence increase and decrease, respectively.

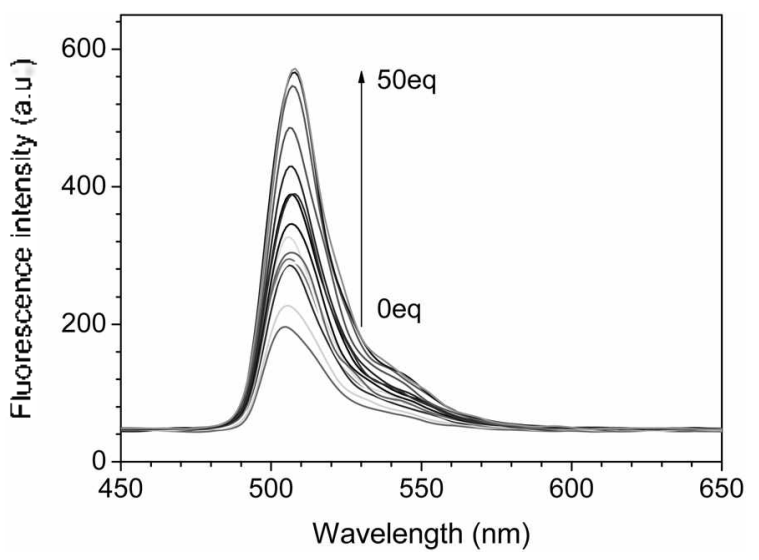

Figure 3. Fluorescence emission spectra of $1(0.50 \mu \mathrm{M})$ for $\mathrm{Hg}^{\frac{1}{2}}$ ion titration in $\mathrm{H}_{2} \mathrm{O} / \mathrm{CH}_{3} \mathrm{CN}(6: 4, w / v) .\left(\lambda_{3 \mathrm{x}}=499 \mathrm{~nm}\right)$.

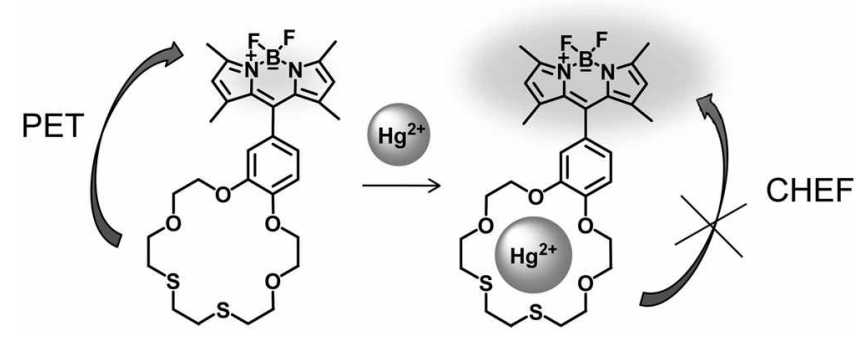

Figure 4. Suggested complexation mechanism of 1 for $\mathrm{Hg}^{2+}$ ion.

Free 1 showed an intense greenish fluorescence at $507 \mathrm{~nm}$. in $\mathrm{H}_{2} \mathrm{O} / \mathrm{CH}_{3} \mathrm{CN}(6: 4$. $\mathrm{v} / \mathrm{v})$ solution $\left(\lambda_{\mathrm{x}}=498 \mathrm{~lm}\right)$. With an excitation at $498 \mathrm{~nm}$, the fluorescence intensity of 1 markedly increased in a function of $\left[\mathrm{Hg}^{2+}\right]$ (Figure 3). According to the extent of the fluorescence emission changes. we could obtain the association constants ${ }^{16}$ of $1\left(K_{\mathrm{a}}=1.59 \times 10^{5} \mathrm{M}^{-1}\right)$ for $\mathrm{Hg}^{-2}$ ion.

We also carried out Job's plot experiment by varying the concentration of both 1 and $\mathrm{Hg}^{2-}$. The maximum point at the mole fraction of 0.5 indicates typical ligand mole fraction for 1:1 (ligand : metal) complexes (Figure 5).

An important feature of chemosensor has to show high selectivity toward specific analyte over other competitive 


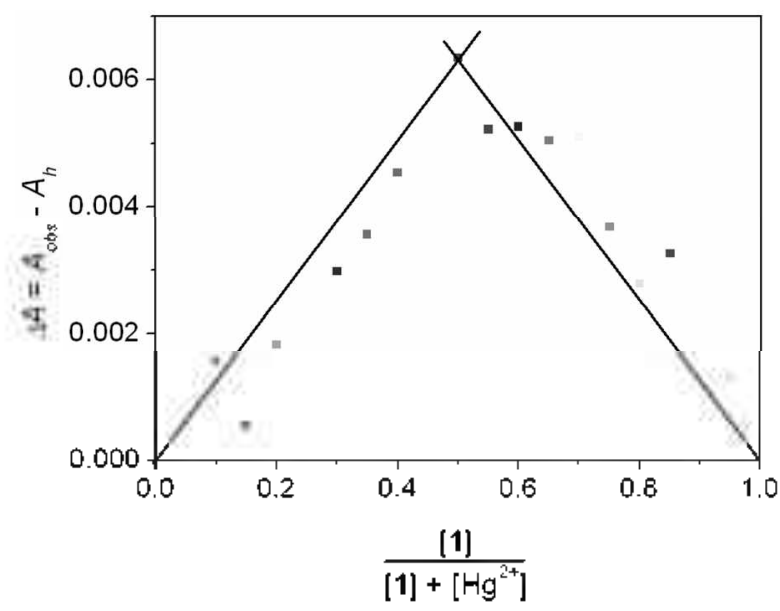

Figure 5. Job plot of a 1:1 complex of 1 and $\mathrm{Hg}^{2+}$ iont.

species. For the $\mathrm{Hg}^{2+}$ ion selectivity of 1 , competition experiments using miscellaneous cations including $\mathrm{Li}^{-} . \mathrm{Na}^{+} . \mathrm{K}^{+}$.

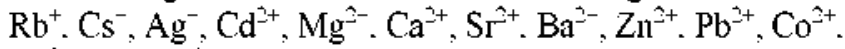
$\mathrm{Cu}^{2^{-}}$. and $\mathrm{Al}^{3-}$ in $\mathrm{H}_{2} \mathrm{O} / \mathrm{CH}_{3} \mathrm{CN}(6: 4$. v/v) were carried out and their results are recorded in Figure 6. The miscellaneous competitive cations did not lead to any significant fluorescence changes. Moreover. in the presence of miscellaneous competitive cations, the $\mathrm{Hg}^{\hat{2}}$ ion still resulted in the sinilar fluorescence increase. In addition, the increases of fluorescence intensity resulting from the addition of the $\mathrm{Hg}^{2-}$ ion was not influenced by the subsequent addition of miscellaneous cations.

\section{Experimental Section}

Precursors 5 and 6 were prepared by adaptation of reported procedures. ${ }^{17}$

Preparation of 1. This compound was prepared from 4 (300 $\mathrm{mg} .1 .1 \mathrm{mmol}$ ) according to a similar procedure outlined above for 3 . The compound was purified by flash column chromatography on silica gel using ethylacetate as eluent. Evaporation of the solvent yielded pale yellow vis- cous oil which upon refrigeration gave the desired product as a pale yellow solid. Yield: $250 \mathrm{mg}(53 \%)$. ${ }^{1} \mathrm{H}$ NMR (400 $\mathrm{MHz}, \mathrm{CDCl}_{3}$ ): $\delta 6.94(\mathrm{~d}, 2 \mathrm{H}, \mathrm{ArH}) .6 .77(\mathrm{~d}, \mathrm{lH}, \mathrm{Ar} H), 5.97$ (s, $2 \mathrm{H}, \mathrm{ArH}$ ). $4.20\left(\mathrm{~m} .4 \mathrm{H} .-\mathrm{OCH}_{2} \mathrm{CH}_{2} \mathrm{O}-\right) .3 .92(\mathrm{~m}, 4 \mathrm{H}$, $-\mathrm{OCH}_{2} \mathrm{CH}_{2} \mathrm{O}$-). 3.80 (m. $4 \mathrm{H}$. $-\mathrm{OCH}_{2} \mathrm{CH}_{2} \mathrm{O}-$ ). $2.88(\mathrm{~s}, 4 \mathrm{H}$, $-\mathrm{SCH}_{2} \mathrm{CH}_{2} \mathrm{~S}$-). 2.80 (q. $4 \mathrm{H}$. $-\mathrm{SCH}_{2} \mathrm{CH}_{2} \mathrm{O}$-) 2.54 (s. $6 \mathrm{H}$, $-\mathrm{Ar} H), 1.46(\mathrm{~s}, 6 \mathrm{H},-\mathrm{Ar} H){ }^{13} \mathrm{C}$ NMR $(100 \mathrm{MHz}, \mathrm{CDCl}): \delta$ 146.9. 143.5, 143.2. 138.2. 129.0, 126.1. 125.6, 121.3. 119.4, $119.2,72.6,69.7,46.4$. 32.8. 29.9. 14.7. 8.8 ppm. FAB MS $m z\left(\mathrm{M}^{-}\right)$: calcd. 590.23 Found, 590.0.

Preparation of 2. This compound was prepared from 5 (300 $\mathrm{mg} .1 \mathrm{mmol}$ ) according to a similar procedure outlined above for 3 . The compound was purified by flash column chromatography on silica gel using ethylacetate as eluent. Evaporation of the solvent yielded pale yellow viscous oil which upon refrigeration gave the desired product as a pale yellow solid. Yield: $300 \mathrm{mg}(57 \%)$. ${ }^{1} \mathrm{H}$ NMR $(400 \mathrm{MHz}$, $\left.\mathrm{CDCl}_{3}\right): \delta 6.95(\mathrm{~d}, 2 \mathrm{H} . \mathrm{Ar} H) .6 .79(\mathrm{~d}, \mathrm{lH}, \mathrm{Ar} H), 5.97(\mathrm{~s}, 2 \mathrm{H}$, $\mathrm{ArH}) .4 .20\left(\mathrm{~m}, 4 \mathrm{H} .-\mathrm{OCH}_{2} \mathrm{CH}_{2} \mathrm{O}-\right) .3 .96\left(\mathrm{~m}, 4 \mathrm{H} .-\mathrm{OCCH}_{2} \mathrm{CH}_{2} \mathrm{O}-\right)$. 3.79 (m. 4H. $\left.-\mathrm{OCH}_{2} \mathrm{CH}_{2} \mathrm{O}-4 \mathrm{H}_{3}-\mathrm{OCH}_{2} \mathrm{CH}_{2} \mathrm{O}-\right) .2 .54(\mathrm{~s}, 6 \mathrm{H}$, $-\mathrm{Ar} H), 1.46(\mathrm{~s}, 6 \mathrm{H},-\mathrm{Ar} H) \cdot{ }^{12} \mathrm{C}$ NMR $\left(100 \mathrm{MHz}, \mathrm{CDCl}_{3}\right): \delta$ $155.7,143.4,130.0 .128 .2$. 121.3, 113.6. 70.9, 70.7, 70.0, 69.5. 68.9. $14.7 \mathrm{ppm}$. FAB MS $m z\left(\mathrm{M}^{-}\right)$: calcd. 514.25 Found, 514.0

Preparation of 3. To a solution of 2,4-dimetlyylpyrrole $(0.18 \mathrm{~g} .1 .89 \mathrm{mmol})$ and $6(0.25 \mathrm{mg} .0 .73 \mathrm{mmol})$ in dried dichloromethane. 2 drops of $\mathrm{CF}_{3} \mathrm{CO}_{2} \mathrm{H}$ was added. The yellow solution was stirred for $3 \mathrm{~h}$ at room temperature under $\mathrm{N}_{2}$. A solution of $p$-chloranil $(0.47 \mathrm{~g} .1 .89 \mathrm{mmol})$ in $\mathrm{CH}_{2} \mathrm{Cl}_{2}(100 \mathrm{~mL})$ was then added. After stirring for $30 \mathrm{~min}$, $\mathrm{Et}_{3} \mathrm{~N}$ and $\mathrm{BF}_{3} \cdot \mathrm{OEt}_{2}$ were subsequently added until a brightgreen fluorescence was observed. The solution was washed with water. and the organic layer was dried over anhydrous $\mathrm{MgSO}_{4}$. Removal of the organic solvent in vacto afforded a reddish solid. Column chromatography on silica gel with EtOAc-hexane (2:1) as eluents gave $0.29 \mathrm{~g}(70 \%)$ of $\mathbf{3} .{ }^{1} \mathrm{H}$ $\operatorname{NMR}\left(400 \mathrm{MHz}, \mathrm{CDCl}_{3}\right.$ ): $\delta 6.95$ (d. $\left.2 \mathrm{H}, \mathrm{Ar} H\right) .6 .76($ d. $\mathrm{lH}$, $\mathrm{ArH}$ ). 5.97 (s. $2 \mathrm{H}, \mathrm{ArH}) .4 .20$ (m. $4 \mathrm{H},-\mathrm{OCH}_{2} \mathrm{CH}_{2} \mathrm{O}$-). 3.98 (m, $4 \mathrm{H},-\mathrm{OCH}_{2} \mathrm{CH}_{2} \mathrm{O}$-). $3.80\left(\mathrm{~m}, 4 \mathrm{H},-\mathrm{OCH}_{2} \mathrm{CH}_{2} \mathrm{O}\right.$-). 3.73
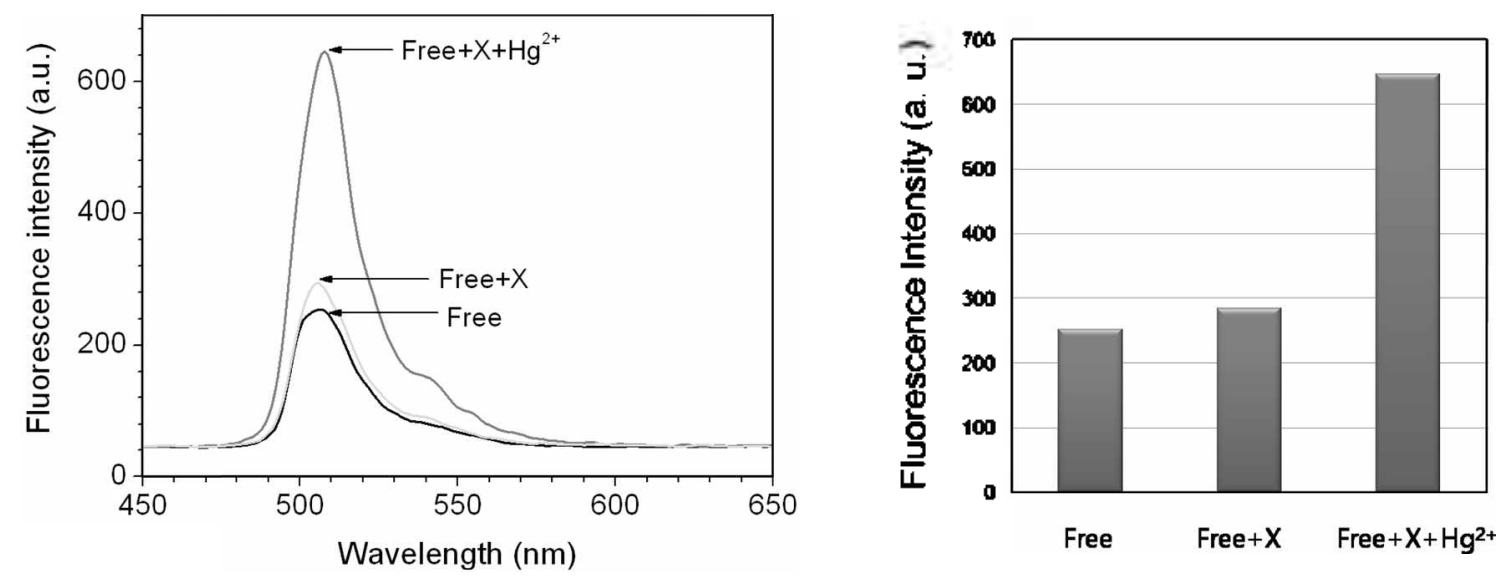

Figure 6. Fluorescence spectra of $1(10, / \mathrm{M})$ in $\mathrm{H}_{2} \mathrm{O} / \mathrm{CH}_{3} \mathrm{CN}(6: 4, v / \mathrm{v})$ in the presence of the $\mathrm{Hg}^{2-}$ ion and miscellaneous cations including $\mathrm{Li}^{-}, \mathrm{Na}^{-}, \mathrm{K}^{-}, \mathrm{Rb}^{+}, \mathrm{Cs}^{-}, \mathrm{Ag}^{+}, \mathrm{Cd}^{2-}, \mathrm{Mg}^{2-}, \mathrm{Ca}^{2-}, \mathrm{Sr}^{2-}, \mathrm{Ba}^{2+}, \mathrm{Zn}^{2+}, \mathrm{Pb}^{2+}, \mathrm{Co}^{2+}, \mathrm{Cul}^{2-}$, and $\mathrm{Al}^{3-}$ (10 equiv, respectively, excitation wavelength at 498 min ). All spectral data were recorded at 10 min after $\mathrm{Hg}^{2+}$ addition. 
(m, $4 \mathrm{H} .-\mathrm{OCH}_{2} \mathrm{CH}_{2} \mathrm{O}-4 \mathrm{H} .-\mathrm{OCH}_{2} \mathrm{CH}_{2} \mathrm{O}-$ ). 2.54 (s, 6H. - $\mathrm{Ar} H$ ), 1.46 (s. $6 \mathrm{H},-\mathrm{Ar} H$ ). ${ }^{13} \mathrm{C}$ NMR ( $\left.100 \mathrm{MHz}, \mathrm{CDCl}_{3}\right): \delta 155.6$. 143.4. 131.9. 131.8, 121.4. 121.3. 121.0, 70.4, 70.3. 70.2. 14.8. $14.7 \mathrm{ppm}$. FAB MS $m z\left(\mathrm{M}^{+}\right)$: calcd. 558.27 Found. 558.0.

Preparation of $t$. A mixture of 3.4-dihydroxybenzaldehyde $(\mathrm{lg} .7 .24 \mathrm{mmol})$ and $\mathrm{K}_{2} \mathrm{CO}_{3}(1 \mathrm{~g} .7 .24 \mathrm{mmol})$ was taken in $\mathrm{CH}_{3} \mathrm{CN}(50 \mathrm{~mL})$. Compound $7(1.43 \mathrm{~g} .7 .23 \mathrm{mmol})$ was added to it with stirring and refluxed under nitrogen atmosphere for 18 hours. The cooled mixture was evaporated to dryness and the residue was extracted with $\mathrm{CHCl}_{3}$ for 3 or 4 times. The extract was evaporated to yield a viscous oil which was purified by colunun chromatography on silica gel columu using $\mathrm{CHCl}_{3}$ (ethyl acetate/hexane, 1:2) as eluent. Yield: $2.1 \mathrm{~g}(77 \%)$. ${ }^{1} \mathrm{H} \mathrm{NMR}\left(400 \mathrm{MHz}, \mathrm{CDCl}_{3}\right): \delta$ 9.83 (s. $\mathrm{lH}, \mathrm{CHO}$ ). 7.46 (d, $2 \mathrm{H}, \mathrm{ArH}), 6.9$ (d. IH, ArH). 4.36 (m, $4 \mathrm{H} .-\mathrm{OCH}_{2} \mathrm{CH}_{2} \mathrm{O}-$ ), 3.93 (m, $8 \mathrm{H} .-\mathrm{OCH}_{2} \mathrm{CH}_{2} \mathrm{O}-$ ), 3.86 (m, $4 \mathrm{H}$. $-\mathrm{OCH}_{2} \mathrm{CH}_{2} \mathrm{~S}$-). 2.95 (s. $4 \mathrm{H}_{3}-\mathrm{SCH}_{2} \mathrm{CH}_{2} \mathrm{~S}$-) 1.22 (s. $\left.4 \mathrm{H}_{3}-\mathrm{OCH}_{2} \mathrm{CH}_{2} \mathrm{O}-\right) .{ }^{13} \mathrm{C}$ NMR $\left(100 \mathrm{MHz}, \mathrm{CDCl}_{3}\right): \delta 190.9$. 155.1. 150.2. 131.1. 127.4. 447.9. 72.8. 72.2. 71.9. 68.9. $32.9,32.0 .29 .9$ ppm. FAB MS $m z\left(\mathrm{M}^{+}\right)$: calcd. 372.11 Found, 372.0

Preparation of 7. Under nitrogen, a solution of 1,2ethanedithiol $(0.5$ g. $5.3 \mathrm{mmol})$, and $\mathrm{NaOH}(0.44 \mathrm{~g} .10 .6$ $\mathrm{mmol})$ in ethanol $(100 \mathrm{~mL})$ was stirred at room temperature. Then 2-(2-chloroethoxy)ethanol (1.38 g. $10.6 \mathrm{mmol})$ was added to it with stirring and refluxed under $\mathrm{N}_{2}$ atmosphere for 2 hours. After stirring for $24 \mathrm{~h}$, the solvent was evaporated in victo. The resulting brownwish oil was used directly for the next reaction. The resulting residue treated with tosyl chloride $(1.47 \mathrm{~g}, 7.4 \mathrm{~mm}$ ol) and $\mathrm{NaOH}(0.3 \mathrm{~g}, 7.7$ mmol) in THF ( $100 \mathrm{~mL})$. After stirring at room temperature for $24 \mathrm{~h}$. the solvent was evaporated in vacto, and the mixture was dissolved in $\mathrm{CH}_{2} \mathrm{Cl}_{2}(100 \mathrm{~mL})$. The organic layer was washed with water $(300 \mathrm{~mL})$ and dried over anhydrous $\mathrm{Na}_{-} \mathrm{SO}_{4}$ and filtered. Purification by colunn chromatography on silica gel (ethyl acetate/hexane, 1:4) provided $1.5 \mathrm{~g}$ of yellowish oil 7 in $50 \%$ yield. ${ }^{1} \mathrm{H}$ NMR $\left(400 \mathrm{MHz}, \mathrm{CDCl}_{\mathrm{s}}\right): \delta 7.74$ (d. $\left.4 \mathrm{H} . \mathrm{Ar} H\right), 7.30($ d. $4 \mathrm{H}, \mathrm{Ar} H)$. $4.06\left(\mathrm{~m}, 4 \mathrm{H},-\mathrm{OCH}_{2} \mathrm{CH}_{3} \mathrm{O}-\right) .3 .59\left(\mathrm{~m}, 4 \mathrm{H},-\mathrm{OCH}_{3} \mathrm{CH}_{3} \mathrm{O}-\right)$. $3.51\left(\mathrm{~m} .4 \mathrm{H},-\mathrm{OCH}_{2} \mathrm{CH}_{2} \mathrm{O}-2\right), 2.66\left(\mathrm{~s}, 4 \mathrm{H},-\mathrm{SCH}_{2} \mathrm{CH}_{2} \mathrm{~S}-\right.$ ). 2.58 (m. $4 \mathrm{H}_{\mathrm{N}}-\mathrm{SCH}_{2} \mathrm{CH}_{2} \mathrm{O}-$ ), 2.37 (s. $6 \mathrm{H} .-\mathrm{OCH}_{2} \mathrm{CH}_{2} \mathrm{O}-$ ). ${ }^{13} \mathrm{C}$ NMR $\left(100 \mathrm{MHz}, \mathrm{CDCl}_{3}\right): \delta 145.1,133.0$. 130.1. 128.1. $71.3,69.4,68.5 .38 .7,37.7,32.8 .32 .1 .31 .6,21.8$ ppm. FAB MS $m z\left(\mathrm{M}^{-}\right)$: calcd. 578.11 Found. 578.0.

Acknowledgments. The authors wish to acknowledge the financial support from the basic science research grant of KRF 2008-C00426 and SRC program (RI1-2005-008$02001-0(2008)$.

\section{References}

1. (a) Chemosensors for Ion and Holecule Recognition. NATO ASI Series: Desvergnes, J. P.: Czarnik. A. W. Eds: Kluwer Academic: Dordrecht, 1997. (b) de Silta, A. P. Gumaratne, H. Q. N.: Gumnlaugsson. T.: Huxley A. I. M.: McCoy. C. P. Rademacher, J. T: Rice, T. E. Chem, Rev 1997,97, 1515. (c) Schmidtchen, F. P.: Berger. M. Chem. Rev: 1997. 97. 1609. (d) Kim. J. S.: Quang. D. T. Chen. Rev 2007, 107,3780.
2. (a) Gale. P. A. Coord. Chent Rev 2000. 199. 181. (b) Fabrizzi. L Coord. Chem. Rev: 2000. 205. 1. (c) Kuswandi. B. Jumal HLM $R$ : DHSRA 2000. 1. 18. (d) Bren. V. A. Russ. Chem. Rev 2001. 70. 1017. (e) Valeur. B. Molecula Fltonscence Wilev-VCH: Weinheim, 2002. (t) Diamond. D.: Nolan, K. Anal Chem 2001. 73. 22A. (g) Lee, Y. O: Choi, Y. H.: Kim, J. S. Bull. Kon: Chem. Soc. 2007. 28(1). 151. (h) Kim. H. J.: Kiml. S. H.: Quan1g. D. T: Kimn. T. H.: Sult. I. W.: Kim. J. S. Bull. Kor Chem. Sa. 2007. 28(5). 811

3. (a) Beer, P. D.: Gale, P. A. Angew. Chem. Int. Ed Engl 2001. 40. 486. (b) Ludwig. R.: Dzung, N. T. K. Sensors 2002, 2. 397. (c) Callan. J. F.: de Silva, A. P.: Magri. D. C. Tetrahedron 2005 . 61. 8551. (d) Dallali. N.: Darabi. A.: Agrawal. Y. K. Rev. Anal Chent. 2005. 24. 263. (e) Amendola. V: Fabbrizzi. I.: Forti. F: Pallavicini. P.: Poggi. A.: Sacchi. D.: Tagleitti. A. Coond Chen. Rev 2006. 250. 273. (1) Mancin, F.: Rampazzo, E.; Tecilla, P: Tonellato. U. Chem. Eur J. 2006. 12, 1844. (g) Kungwandi, B: Nuriman: Verboom, W.: Reinhoudt, D. N. Sensors 2006, 6,978. (h) Zhu. L.: Anslyn. E. V. Angew. Chen., Int. Ed 2006. 45. 1190. (i) Valeur. B.: Leray. I. Inorg. Chem. Acta 2007. 360. 765. (j) Anslyn. E. V. J. Ong Chem. 2007. 72.687.

4. Löhr. H.-G.; Vögtle, F. Acc. Chem. Res. 1985. 18,65.

5. Chartres, J. D.: Davies. M. S.; Lindoy. L. F.; Meehan, G. V:; Wei. G. Inorg. Chem. Commm. 2006.9.751.

6. Ikeda. K.: Ale. S. Anal. Chim. Acta 1998.363. 165

7. Matsushita. M. T.: Shono. T. Polbhe dron 1984. 3. 1357.

8. Groth. A. M.: Lindoy. L. F.: Meehan1. G. V. J. Chem. Soc., Perkin Trans. 11996.1553.

9. Lindoy, L. F.: Baldwin. D. S. Pwe Appl. Chem 1989, 61,909

10. Tanaka, M: Nakamura M. Ikeda, T.: Ikeda. K.: Ando, H. Shibutani. Y: Yajima. S.: Kimura. K. J. Org. Chem. 2001. 66. 7008.

11. (a) Beer. G.: Rurack. K.: Daub. J. Chem. Contmum 2001. 1138. (b) Moon. Y. S.: Cha. N. R.: Kiml. Y. H.: Chang. S. K. J. Ong Chent. 2004. 69. 181. (c) Gareis. T: Huber, C.: Woltbeis. O. S.: Daub. J Chem. Commm. 1997, 1717. (d) Rurack. K.: Kollmannsberger. M:- Daub. J. Kew J. Chem. 2001. 25. 289. (e) DiCesare. N.: Lakowicz. J. R. Tetrahedron Lett. 2001. 42. 9105 . (f) Baki. C. N.: Akkaya. E. U. J. Org. Chent 2001. 66. 1512. (g) Turfan. B.: Akkaya. E. U. Ong Lett. 2002. 4. 2857.

12. (a) Kim. S. K.: Lee, S. H.; Lee. J. Y.; Lee, J. Y.: Bartsch, R. A. Kim. J. S. J. Am. Chem. Soc 2004, 126. 16499. (b) Kim, S. K.; Bok. J. H: Bartsch, R. A.: Lee. J. Y; Kim, J. S. Org. Lett. 2005, 7. 4839. (c) Kim. S. K.: Kim. S. H.: Kim. H. J.: Lee. S. H.: Lee. S. W: Ko. J.: Bartsch. R. A.: Kim. I. S. hong Chent 2005 . H. 7866 (d) Kiml. H. J.: Park. S. Y.: Yoont. S.: Kim. T. S. Tetrohedron 2008. 64. 1294 (e) Lee, M. H. Kim. H. J.: Yoon. S.: Park. N.: Kim. J. S. Org. Lett. $2008,10,213$. (f) Lee. M. H.: Wu. J.-S.: Lee, J. W: Jung. J. H; Kim, J. S. Org. Lett. 2007. 9, 2501. (g) Wu, J.-S.: Hwang. I.-C.: Kim. K. S.: Kiml. J. S. Ong. Lett. 2007. 9. 907.

13. (a) Wolte. M. F.: Schwalzbach. S.: Sulainmant. R. A. Enwront. Toxicol. Chem, 1998. 17. 146. (b) Renzoni. A.: Zino. F.: Franchi. E. Emim. Res, 1998, 77, 68. (c) Feng. X. B.; Tang. S. L: Li, Z. G.: Wang. S. F, Liang. L. Chim. Sci. Bull. 2004, 19. 2068. (d) Chen. C. Y.: Zhang. P. Q. Chai. Z. F. Chin. Sci. Bull. 2005, 50. 113. (e) Wang. N.: Zhu. Y. M.: Sheng. L. X.: Meng. D Chin. Sci Bull. 2005. 50. 2166. (f) Harris. H. H.: Pickering. I. T.: George. G. N. Science 2003. 301.1203.

14. Kim. H. J.: Kim. J. S. Tetrahedron Lett. $\mathbf{2 0 0 6},+7,7051$

15. Lee. H. N.; Kim. H. N.: Swamy, K. M. K.: Park. M. S.; Kim. J.; Lee. H.: Lee, K.-H.: Park, S: Yoon. J. Tetahedron Lett. 2008 , 19 1261 .

16. Association constants were obtained using the computer program ENZFITTER. available from Elsevier-BIOSOFT. 68 Hills Road. Cambridge CB2 lLA. United Kingdom: Connors. K. A. Binding Constants' Wiley: New York. 1987.

17. (a) Sousa C.: Freire C.: de Castro, B. Molecules 2003, 8, 894. (b) Reinhoudt. D. N.: de Tong. F.: Tomassen. H. P. M. Tetrohedhon Lett. 1979. 20. 2067. 